\title{
Seleksi karakter kandungan amilosa sedang pada populasi hasil persilangan Sintanur x PTB33 dan Pandanwangi x PTB33 berdasarkan marka fenotipik dan molekuler SSR
}

\author{
Selection medium amylose content character of population derived \\ from a cross between Sintanur x PTB33 and Pandanwangi x PTB33 \\ based on phenotypic and SSR molecular marker
}

Diterima : 30 Agustus 2018/Disetujui : 14 Desember 2018 / Dipublikasikan : 31 Desember 2018

CDepartment of Crop Science, Padjadjaran University

\begin{abstract}
Medium amylose rice is a special type of rice that is highly demand by people in Asia and the world. Purpose of this study is to obtain individual F7 progeny (came from a cross between Sintanur $x$ PTB33 and Pandanwangi $x$ PTB33) with medium amylose content. Materials used were spectrophotometer with wave lenght $625 \mathrm{~nm}$, meanwhile molecular markers applied were Wx. Results of this study showed that SP73-3-1-7 had usually most use the plant with medium amylose content (20-24\%) based on molecular and phenotypic marker. The combination of both tests provides more accurate in selecting physicochemical trait in rice.
\end{abstract}

Keywords: Rice $\cdot$ Molecular marker $\cdot$ Amylose content $\cdot$ Spektrophotometer

Sari. Padi dengan kandungan amilosa sedang sangat diminati oleh masyarakat Asia dan Dunia. Tujuan dari penelitian ini adalah untuk memperoleh individu keturunan $\mathrm{F}_{7}$ (yang berasal dari hasil persilangan Sintanur x PTB33 dan Pandanwangi x PTB33) dengan kandungan amilosa sedang. Alat yang digunakan untuk analisis kandungan amilosa yaitu spektrofotometer dengan panjang gelombang $625 \mathrm{~nm}$, sedangkan marka molekuler menggunakan marka Wx. Hasil dari penelitian ini menunjukkan bahwa SP73-3-1-7 memiliki jumlah tanaman paling banyak yang

Dikomunikasikan oleh Sosiawan Nusifera Slamet, W.Y. ${ }^{1} \cdot$, R.S.W. Anita ${ }^{2}$. S. Santika ${ }^{3}$. C, Nono $^{4}$

${ }^{1}$ Mahasiswa Program S2 Pemultan Universitas Padjadjaran

2 Mahasiswa Program S1 Pemultan Universitas Padjadjaran

3,4 Dosen Departemen Budidaya Tanaman Fakultas

Pertanian Universitas Padjadjaran

Korespondensi: n.carsono@unpad.ac.id mengandung amilosa yang sedang (20-24\%) berdasarkan marka molekuler dan fenotipik. Kombinasi kedua pengujian ini akurat dalam menyeleksi karakter fisikokimia padi.

Kata kunci: Padi • Marka molekuler . Kandungan amilosa $\cdot$ Spektrofotometer

\section{Pendahuluan}

Padi (Oryza sativa L.) merupakan tanaman penghasil beras yang menjadi pangan pokok sekitar 95\% masyarakat Indonesia (Badan Pusat Statistik, 2018). Beras sebagai pangan pokok mengandung nutrisi yang cukup tinggi. Menurut Indriyani et al. (2013), pada 100 gram beras mengandung 78\% karbohidrat, 6,7\% protein, 3,6\% lemak, 1,4\% glukosa, $0,4 \%$ serat. Kandungan glukosa pada beras dapat berisiko menimbulkan masalah diabetes yang ditandai oleh kenaikan gula darah.

Prevalensi penderita diabetes di Indonesia pada tahun 2016 berkisar 10 juta jiwa dan diperkirakan pada tahun 2025 penderita diabetes mencapai 12,4 juta jiwa. Diabetes merupakan sekelompok penyakit yang mengakibatkan kadar gula dalam darah tinggi (World Health Organization., 2016).

Permasalahan diabetes salah satunya dapat diatasi dengan perakitan padi yang tidak mudah tergelatinisasi sehingga tidak drastis menaikan kadar gula darah apabila dikonsumsi. Hal tersebut sangat dipengaruhi penyusun pati. Pati tersusun atas dua macam polisakarida yaitu amilosa dan amilopektin. Amilosa merupakan polimer gula linear yang terdiri dari unit monosakarida atau sering disebut dengan 
polisakarida, sedangkan amilopektin merupakan polimer glukosa dengan ikatan bercabang (Champagne, 2008). Semakin panjang rantai polisakarida maka semakin sulit dipecah melalui proses hidrolisis sehingga beras menjadi pera. Berbanding terbalik dengan amilopektin yang terdiri dari cabang polisakarida, sehingga mudah pecah melalui proses hidrolisis, struktur beras pun menjadi pulen (Shannon et al., 2009).

Berdasarkan kandungan amilosa, beras dapat dibedakan menjadi beras ketan (kadar amilosa $10-20 \%$ ), beras beramilosa sedang (kadar amilosa 20-25\%) dan beras beramilosa tinggi (>25\%) (Sekretariat Jenderal Kementerian Pertanian, 2015). Beras dengan kandungan amilosa sedang tidak terlalu sulit dicerna karena struktur tidak terikat terlalu kuat sehingga memiliki rasa pulen.

Menurut Hsu et al. (2014), kandungan amilosa dikendalikan secara kuantitatif dengan gen mayor $\mathrm{Wx}$ yang memiliki enzim aktif memengaruhi produksi granule-bound starch synthase (GBSS). Ekspres dari gen ini dapat diamati melalui analisis fenotipik dan marka molekuler. Kedua metode tersebut bisa membedakan tingkat kandungan amilosa padi. Kombinasi kedua pengujian tersebut dapat memberikan informasi yang lebih akurat mengenai kandungan amilosa padi.

Kandungan amilosa padi dapat dianalisis menggunakan marka fenotipik, sedangkan keberadaan gen $\mathrm{Wx}$ pengendali kandungan amilosa dapat dideteksi dengan marka molekuler spesifik. Marka ini terkait erat dengan gen Wx yang mengendalikan ekspresi karakter amilosa. Gen Wx terletak pada kromosom 6 (Hsu et al., 2014). Penelitian ini dilakukan dengan menggunakan keturunan $\mathrm{F}_{7}$ dari persilangan Sintanur x PTB-33(SP) dan Pandanwangi $x$ PTB-33(PP). Sintanur dan Pandanwangi merupakan varietas lokal Indonesia dengan kandungan amilosa sedang (18-24\%) (Balai Besar Penelitian Tanaman Padi, 2009). Sintanur juga mudah beradaptasi dengan lingkungan (Indeks adapatasi relatif tinggi 1.16-1.29) (Ruminta et al., 2016). PTB-33 merupakan varietas hasil introduksi dari India yang memiliki kandungan amilosa tinggi dan tahan wereng coklat (Balai Besar Penelitian Tanaman Padi, 2012). Tujuan dari penelitian ini adalah menyeleksi genotip baru yang memiliki kandungan amilosa sedang. Seleksi berbasis marka molekuler $\mathrm{F}_{7}$ untuk kandungan amilosa sedang belum dilakukan. Sebagai upaya yang efektif untuk mencapai target, evaluasi kandungan amilosa sedang untuk pengujian $\mathrm{F}_{7}$ diperlukan melalui analisis fenotipik menggunakan spektrofotometer dengan panjang gelombang $625 \mathrm{~nm}$ dan marka molekuler.

\section{Bahan dan Metode}

Empat belas genotip keturunan $\mathrm{F}_{6}$ hasil persilangan Sintanur x PTB-33(SP) dan Pandanwangi $x$ PTB-33(PP) dievaluasi. Masing-masing genotip terdiri dari empat puluh tanaman, sehingga jumlah total sampel 560 tanaman. Sampel beras dikumpulkan untuk pengujian fenotipik, sedangkan marka molekuler menggunakan sampel daun. Analisis data molekuler dilakukan dengan membandingkan pola pita DNA yang terbentuk dari setiap genotip uji dengan tetua persilangannya. Skoring pita DNA yang terbentuk digunakan sebagai nilai dalam analisis korelasi untuk mengetahui hubungan antara marka yang digunakan beserta gen yang terkait dengan karakter fisiologis yang muncul pada tetua persilangan. Skoring pita DNA yang tervisualisasi, dibedakan berdasarkan (1) ada pita dan (0) jika tidak ada pita DNA. Analisis data fenotipik dilakukan dengan mengelompokkan data kedalam kriteria rendah, sedang dan tinggi, sehingga dapat diambil kesimpulan genotip mana yang memiliki jumlah individu paling banyak dengan kandungan amilosa sedang. Analisis keterkaitan antara marka molekuler dan fenotipik dihitung menggunakan metode korelasi non-parametrik Spearman rho pada software SPSS. Adanya korelasi menunjukkan bahwa marka molekuler dapat digunakan sebagai acuan dalam mendeteksi atau menyeleksi gen target. Keeratan hubungan antar marka molekuler dan fenotipik berdasarkan nilai $r$. Nilai $r=0,80-1,00$ menunjukkan adanya keterkaitan yang sangat kuat; 0,60-0,799 keterkaitan kuat, 0,40-0,599 keterkaitan sedang; 0,20-0,399 keterkaitan rendah dan 0,00-0,199 keterkaitan sangat rendah (Santoso, 2002). Seluruh karakter pengamatan dilakukan skoring pembobotan untuk mengetahui genotip yang memiliki penampilan terbaik untuk karakter kandungan amilosa. Nilai bobot terbesar yang dimiliki oleh genotip yang diuji nantinya akan mengindikasikan genotip yang diduga memiliki kandungan amilosa sedang berdasarkan penilaian marka 
fenotipik dan molekuler. Pembobotan dilakukan dengan memberi skor pada kriteria amilosa sedang

Analisis kandungan amilosa padi. Dilakukan menggunakan spektrofotometer dengan panjang gelombang $625 \mathrm{~nm}$ (IRRI, 2009). Beras digerus hingga menjadi tepung, ditimbang sebanyak $1 \mathrm{mg}$, dimasukan dalam mikrotube lalu ditambahkan $10 \mu \mathrm{l}$ etanol $95 \%$ dan $90 \mu \mathrm{l}$ larutan $\mathrm{NaOH} 1 \mathrm{~N}$. Kemudian diinkubasi pada suhu $95^{\circ} \mathrm{C}$ selama 10 menit lalu diencerkan dengan aquades sampai volume $1 \mathrm{ml}$. Diambil sebanyak $50 \mu$ larutan, kemudian dimasukkan dalam microtube $2 \mathrm{ml}$, ditambahkan $20 \mu \mathrm{l}$ iodine dan $10 \mu \mathrm{l}$ asam asetat $1 \mathrm{~N}$. Selanjutnya diencerkan kembali dengan akuades sampai 1 $\mathrm{ml}$, larutan tersebut dikocok lalu didiamkan selama 20 menit. Kemudian dianalisis menggunakan spektrofotometer $625 \mathrm{~nm}$.

Ekstraksi DNA dan amplifikasi PCR. Ekstrasi DNA dari daun muda dilakukan dengan metode CTAB (Doyle dan Doyle, 1987). Kualitas DNA dianalisis dengan menggunakan elektroforesis. Elektroforesis kualitas DNA dilakukan menggunakan $2 \%$ gel agarose yang dilarutkan dalam $100 \mathrm{ml}$ TBE 0,5x. Proses elektroforesis dilakukan pada tegangan dan durasi tertentu sesuai dengan primer, kemudian direndam dalam larutan EtBr (ethidium bromide) selama 30 menit dan dalam air destilasi selama 10 menit.

Identifikasi gen $\mathrm{Wx}$ dilakukan dengan menggunakan primer spesifik. PCR dilakukan dengan menggunakan $1 \mu \mathrm{l}$ DNA genom $20 \mu \mathrm{l}^{-1}$, $5 \mu \mathrm{KAPPA}, 1 \mu \mathrm{l}$ primer $\mathrm{Wx}$ pada volum total 10 $\mu$ l. Produk PCR dianalisis menggunakan elektroforesis (ethidium bromide (0,5 ug mL-1), $2.0 \%$ gel agaros dan $100 \mathrm{bp}$ ladder).

\section{Hasil dan Pembahasan}

Amilosa merupakan polimer glukosa dengan ikatan a-(1-4) glukosidik. Berdasarkan kandungan amilosa, beras dapat dibedakan menjadi beras ketan (kadar amilosa 10-20\%), beras beramilosa sedang (kadar amilosa 20-25\%) dan beras beramilosa tinggi ( $>25 \%$ ) (Internasional Board for Plant Genetic Resources, 1980). Data kandungan amilosa sedang yang diamati dalam penelitian ini dapat dilihat pada Tabel 1. Jumlah tanaman (n) yang diamati per genotip ialah 40 tanaman. Perhitungan dilakukan dalam bentuk persentase.

Pada penelitian ini, genotip uji memiliki kandungan amilosa terendah yaitu $15 \%$ dan yang tertinggi yaitu $27 \%$. Struktur amilosa yang berbeda menyebabkan daya cerna dan respon glikemik yang berbeda. Kandungan amilosa sering digunakan untuk memprediksi tingkat kecernaan pati dan indeks glikemik respon glukosa darah. Beras dengan kandungan amilosa tinggi akan sulit tergelatinisasi, sehingga tidak secara drastis menaikan kadar gula darah tubuh, namun memiliki tekstur yang pera. Beras dengan kandungan amilosa sedang tidak mudah tergelatinisasi dan memiliki rasa yang pulen sehingga beras dengan kandungan amilosa sedang disukai oleh para penderita diabetes. Beras dengan kandungan amilosa rendah akan mudah tergelatinisasi sehingga drastis menaikan kadar gula darah apabila dikonsumsi. Oleh karena itu, seleksi beras dengan kandungan amilosa sedang penting untuk dilakukan. Berdasarkan pengamatan secara fenotipik terdapat satu genotip yang memiliki individu terbanyak dengan kandungan amilosa sedang yaitu genotip SP73-3-1-7.

Tabel 1. Persentase genotip padi yang memiliki kandungan amilosa sedang dengan pengujian secara fenotipik (spektrofotometer).

\begin{tabular}{ccc}
\hline Genotip & Fenotipik (\%) & Ranking \\
\hline SP73-3-1-7 & 55 & 1 \\
SP73-3-1-15 & 12,5 & 12 \\
SP73-3-1-27 & 40 & 3 \\
PP48-3-1-6 & 40 & 5 \\
SP73-3-1-8 & 37,5 & 6 \\
SP73-3-1-5 & 12,5 & 13 \\
SP73-3-1-33 & 47,5 & 7 \\
SP73-3-1-29 & 50 & 2 \\
SP73-3-1-37 & 35 & 4 \\
SP87-1-1-7 & 15 & 11 \\
SP73-3-1-2 & 15 & 9 \\
SP73-1-1-17 & 5 & 14 \\
SP46-4-1-44 & 25 & 8 \\
SP87-24-1-28 & 17,5 & 10 \\
\hline
\end{tabular}

Kandungan amilosa dikontrol oleh gen mayor waxy $(W x)$. Terdapat lima variasi alel pada lokus Wx yakni $W x^{a}, W x^{i n}, W x^{b}, W x^{o p}$ dan $w x$. Gen waxy mengkode granule bound starch synthase (GBSS) yang terletak pada kromosom 6 (Bao et al., 2006). GBSS terakumulasi selama proses pengisian gabah. Pada lokus Wx juga terdapat dua alel fungsional yaitu $w x^{a}$ dan $w x^{b}$ yang banyak ditemukan pada subspesies indica dan japonica. Kandungan GBSS disintesis lebih banyak oleh alel $w x^{a}$. Kedua alel memproduksi $W x$ protein dengan tingkat yang berbeda pada 
endosperm sehingga menyebabkan variasi pada kandungan amilosa (Crofts et al., 2012).

Berdasarkan pengamatan secara marka molekuler, hasil visualisasi primer Wx terkait kandungan amilosa sedang, menunjukan adanya polimorfisme pada media 8\% PAGE (Gambar 1).

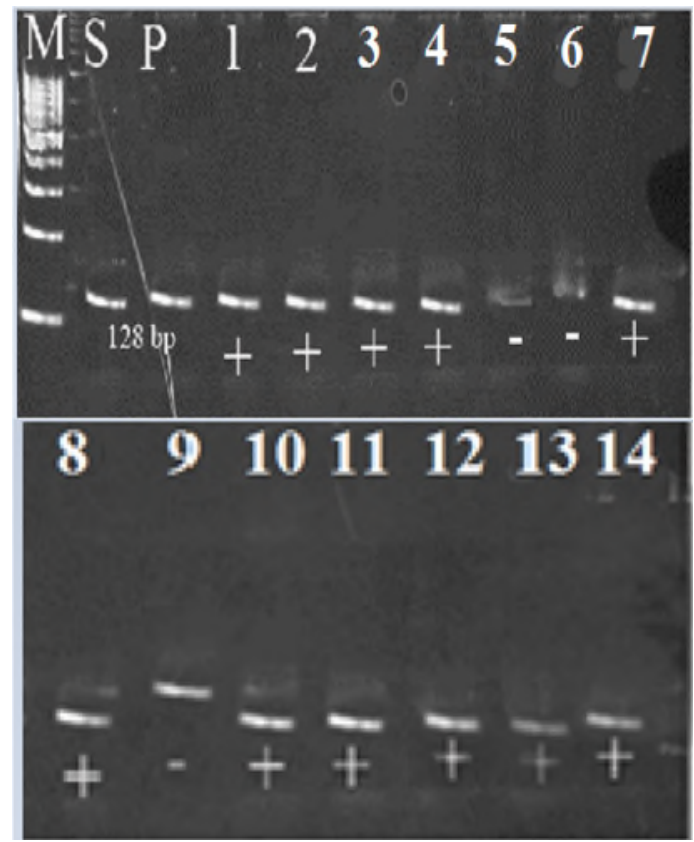

Gambar 1. Visualisasi gel elektroforesis untuk karakter amilosa berdasarkan primer Wx. Ket : $\mathbf{M}=$ ladder $100 \mathrm{bp}$; $\mathrm{S}=$ Sintanur; $\mathrm{P}=$ Pandanwangi; Genotip \#6 = hasil persilangan Pandanwangi $x$ PTB33, \#1-\#5 dan \#7- \#14= Hasil persilangan Sintanur x PTB33; (+) = pola pita DNA sesuai dengan target yang diinginkan (kandungan amilosa rendah-sedang); (-) = pola pita DNA tidak sesuai dengan target yang diinginkan.

Terdapat dua pola pita yang terbentuk pada tetua dan genotip uji hasil visualisasi menggunakan primer Wx dengan media 8\% polyacrylamide gel (PAGE) yakni ukuran pita 128 bp dan 130 bp. Terdapat 11 genotip SP yang memiliki kandungan amilosa rendah/sedang dengan ukuran pola pita yang sama dengan Sintanur yaitu \#1, \#2, \#3, \#4, \#7, \#8, \#10, \#11, \#12, \#13, \#14, sedangkan genotip PP yang diuji tidak memiliki pola pita yang sama dengan Pandanwangi. Menurut hasil penelitian Irmayanti (2014), primer Wx dapat digunakan untuk menyeleksi kandungan amilosa rendah-sedang. Kandungan amilosa dikendalikan oleh single gen dengan major effect bersama dengan beberapa gen minor dan atau modifikasinya (Kumar dan Khush, 1986).
Keterkaitan antara marka molekuler dan marka fenotipik. Analisis korelasi dilakukan untuk mengetahui keterkaitan dan kuat lemahnya hubungan antara marka molekuler yang digunakan dengan karakter terkait yang diamati secara fenotipik. Metode korelasi yang digunakan pada penelitian ini ialah korelasi Spearman rho pada software SPSS. Keterkaitan yang sangat kuat dapat dilihat dari nilai $r=0.80$ 1.00, keterkaitan kuat apabila $r=0.60-0.799$, keterkaitan sedang apabila $r=0.40-0.599$, keterkaitan rendah apabila $r=0.20-0.399$ dan 0.00-0.199 keterkaitan sangat rendah (Santoso, 2002). Hasil analisis korelasi Spearman rho pada marka molekuler dan fenotipik dapat dilihat pada Tabel 2.

Tabel 2. Korelasi marka molekuler dan fenotipik berdasarkan hasil korelasi Spearman rho.

\begin{tabular}{ccccc}
\hline $\begin{array}{c}\text { Marka } \\
\text { molekuler }\end{array}$ & $\begin{array}{c}\text { Marka } \\
\text { fenotipik }\end{array}$ & $\mathrm{n}$ & P-value & $\mathrm{r}(\mathrm{AB})$ \\
\hline $\mathrm{Wx}$ & Amilosa & 560 & 0.000 & $0.645^{* *}$ \\
\hline${ }^{*}=$ signifikan, ${ }^{* *}=$ sangat signifikan & &
\end{tabular}

Berdasarkan hasil analisis dapat dilihat bahwa terdapat korelasi yang positif antara marka Wx dengan kandungan amilosa yakni sebesar 0.645**. Keterkaitan hubungan Wx terhadap kandungan amilosa relatif kuat dan signifikan karena nilai P atau Sig. sebesar 0.000 atau lebih kecil dari tingkat kesalahan 0.05 (5\%). Hubungan kedua variabel yang sangat signifikan dapat dilihat dari tanda bintang dua **. Hal ini menunjukkan bahwa marka Wx dapat digunakan sebagai marka penyeleksi karakter kandungan amilosa.

Korelasi antara marka molekuler dengan karakter target dapat digunakan sebagai alat untuk mempercepat evaluasi genotip uji (Khan, 2009). Pada penelitian ini, marka yang digunakan memiliki hubungan yang kuat dengan karakter yang diuji.

Berdasarkan data pengamatan marka molekuler dan fenotipik juga dapat disajikan tabel kompilasi data (Tabel 3) yang menampilkan genotip-genotip uji yang telah teridentifikasi baik secaara marka molekuler dan fenotipik terkait karakter target yang diinginkan.

Hasil kompilasi data ini diharapkan nantinya dapat menentukan genotip mana yang bisa direkomendasikan untuk dilanjutkan pada uji lanjutan penelitian tentang fisikokimia padi. Tabel 3 menunjukkan bahwa sepuluh genotip uji 
teridentifikasi memiliki gen Wx terkait kandungan amilosa berdasarkan marka molekuler Wx. Hal ini didukung juga dengan hasil evaluasi kandungan amilosa menggunakan Spektrofotometer dengan panjang gelombang $625 \mathrm{~nm}$. Hasil pengamatan karakter kandungan amilosa terdapat 12 genotip memiliki kandungan amilosa dengan kategori sedang. Hal ini terjadi diduga karena adanya faktor pembatas seperti iklim seperti cahaya, suhu dan air, sehingga beberapa genotip uji memiliki amilosa rendah.

Tabel 3. Kompilasi hasil analisis marka molekuler dan fenotipik pada 14 genotip uji.

\begin{tabular}{ccc}
\hline & $\begin{array}{c}\text { Marka } \\
\text { Molekuler }\end{array}$ & Marka Fenotipik \\
\cline { 2 - 3 } & Wx & Amilosa \\
\hline SP73-3-1-7 & + & $\mathrm{S}$ \\
SP73-3-1-15 & + & $\mathrm{S}$ \\
SP73-3-1-27 & + & $\mathrm{S}$ \\
PP48-3-1-6 & + & $\mathrm{S}$ \\
SP73-3-1-8 & + & $\mathrm{S}$ \\
SP73-3-1-5 & - & $\mathrm{S}$ \\
SP73-3-1-33 & + & $\mathrm{S}$ \\
SP73-3-1-29 & + & $\mathrm{S}$ \\
SP73-3-1-37 & - & $\mathrm{S}$ \\
SP87-1-1-7 & + & $\mathrm{S}$ \\
SP73-3-1-2 & - & $\mathrm{R}$ \\
SP73-1-1-17 & + & $\mathrm{S}$ \\
SP46-4-1-44 & + & $\mathrm{S}$ \\
SP87-24-1-28 & + & $\mathrm{R}$ \\
\hline R = rendah, S = sedang &
\end{tabular}

Tabel 4. Perangkingan genotip padi yang memiliki kandungan amilosa sedang terbanyak dengan pengujian secara fenotipik (spektrofotometer) dan marka molekuler.

\begin{tabular}{|c|c|c|c|c|}
\hline Genotip & $\begin{array}{c}\sum \text { Fenotipik } \\
(\%)\end{array}$ & $\begin{array}{c}\sum \text { Marka } \\
\text { moleku- } \\
\text { ler }(\%)\end{array}$ & $\begin{array}{l}\text { Pembo- } \\
\text { botan (\%) }\end{array}$ & $\begin{array}{l}\text { Rank- } \\
\text { ing }\end{array}$ \\
\hline SP73-3-1-7 & 55 & 77 & 66 & 1 \\
\hline SP73-3-1-15 & 12,5 & 29,5 & 21 & 12 \\
\hline SP73-3-1-27 & 40 & 66 & 53 & 3 \\
\hline PP48-3-1-6 & 40 & 60 & 50 & 5 \\
\hline SP73-3-1-8 & 37,5 & 57,5 & 47,5 & 6 \\
\hline SP73-3-1-5 & 12,5 & 31,5 & 22 & 13 \\
\hline SP73-3-1-33 & 47,5 & 37,5 & 42,5 & 7 \\
\hline SP73-3-1-29 & 50 & 80 & 65 & 2 \\
\hline SP73-3-1-37 & 35 & 69 & 52 & 4 \\
\hline SP87-1-1-7 & 15 & 29 & 22 & 11 \\
\hline SP73-3-1-2 & 15 & 45 & 30 & 9 \\
\hline SP73-1-1-17 & 5 & 25 & 15 & 14 \\
\hline SP46-4-1-44 & 25 & 45 & 35 & 8 \\
\hline SP87-24-1-28 & 17,5 & 36,5 & 27 & 10 \\
\hline
\end{tabular}

Langkah selanjutnya dilakukan skoring pembobotan untuk mengetahui genotip yang memiliki penampilan terbaik untuk karakter kandungan amilosa sedang berdasarkan fenotipik dan marka molekuler. Pada penelitian ini, setiap genotip uji terdiri dari 40 tanaman sehingga persentase dilakukan per 40 tanaman (Tabel 4). Nilai bobot terbesar yang dimiliki oleh genotip yang diuji nantinya akan mengindikasikan genotip yang diduga memiliki kandungan amilosa sedang berdasarkan marka fenotipik dan molekuler. Pembobotan dilakukan dengan memberi skor pada kriteria amilosa sedang.

Berdasarkan nilai pembobotan dan ranking yang disusun berdasarkan karakter amilosa sedang tersaji pada Tabel 4, terlihat bahwa genotip yang nilai bobotnya paling tinggi ialah genotip SP73-3-1-7. Pada penelitian ini, SP73-31-7 terseleksi menggunakan spektrofotometer dengan panjang gelombang $625 \mathrm{~nm}$ dan berdasarkan marka molekuler memiliki jumlah tanaman dengan kandungan amilosa sedang terbanyak. Sehingga SP73-3-1-7 terseleksi berdasarkan kedua pengujian tersebut.

Genotip SP73-3-1-7 merupakan genotip hasil persilangan Sintanur $x$ PTB33, yang sebelumnya pada generasi F3 telah terseleksi toleran wereng cokelat dan pada F4 dan F5 terseleksi memiliki daya hasil tinggi. Varietas Sintanur diketahui memiliki mutu beras tinggi dengan tekstur pulen, agak tahan wereng coklat dan baik ditanam di lahan sawah irigasi dataran rendah sampai $550 \mathrm{mdpl}$ (Balai Besar Penelitian Tanaman Padi, 2009). PTB33 memiliki karakter ketahanan terhadap wereng coklat, memiliki tekstur pera dan ukuran tanaman yang tinggi.

\section{Kesimpulan dan Saran}

Genotip SP73-3-1-7 memiliki paling banyak individu tanaman dengan kandungan amilosa sedang berdasarkan analisis menggunakan spektrofotometer dan marka molekuler, sehingga dapan direkomendasikan bagi penderita diabetes karena tidak menaikan kadar gula darah secara drastis dan memiliki rasa yang pulen. Kandungan amilosa bersifat poligenik sehingga kandungan amilosa pada genotip padi F7 yang digunakan dalam penelitian ini masih bersegregasi maka penanaman pada generasi selanjutnya sebaiknya tidak menggunakan rancangan. 


\section{Ucapan Terima Kasih}

Penulis ingin mengucapkan terima kasih kepada Kemenristek Dikti atas pendanaan penelitian ini melalui hibah PUPTN yang diberikan kepada Nono Carsono.

\section{Daftar Pustaka}

Badan Pusat Statistik. 2018. Sensus pertanian tanaman pangan padi. Melalui http://st2013.bps.go.id/dev2/index.php / site/ topik?kid=2\&kategori=TanamanPangan-(Padi-dan-Palawija)

Balai Besar Penelitian Tanaman Padi. 2009. Deskripsi Varietas Padi. BB Padi, Departemen Pertanian

Balai Besar Penelitian Tanaman Padi. 2012. Melalui http://bbpadi.litbang.deptan.go.id/.

Balai Besar Penelitian Tanaman Padi. 2012. Analisis Amilosa. Sukamandi

Bao, J. S., H. Corke and M. Sun. 2006. Microsatellites, single nucleotide polymorphisms and a sequence tagged site in starch-synthesizing genes in relation to starch physicochemical properties in nonwaxy rice (oryza sativa L.) Theor Appl Genet 113: 1185-1196.

Champagne, E. T. 2008. Rice aroma and flavor: a literature review. Cereal Chem.85:445-454.

Crofts, N., K. Abe, S. Aihara, R. Itoh, Y. Nakamura, K. Itoh, and N. Fujita. 2012. Lack of starch synthase IIIa and high expression of granule-bound starch synthase I synergistically increase the apparent amylose content in rice endosperm. Plant Science 193-194 (2012) 62-69.

Doyle, J.J., and J.L. Doyle. 1987. Isolation of plant DNA from fresh tissues. Focus Vol.12: 13-15.

Hsu, Y.-C., M.-C. Tseng, Y.-P. Wu, M.-Y. Lin, F. Wei, K.-K. Hwu, Y. Hsing, and Y.-R. Lin. 2014. Genetic factors responsible for eating and cooking qualities of rice grains in a recombinant inbred population of an inter-subspecific cross. Mol. Breed. 34: 655-673.

IBPGRI-IRRI Rice Advisory Committee. 1980. Descriptors for Rice (Oryza sativa L.).
International Rice Research Institute and International Board for Plant Genetic Resources. Philippines. 21 p.

Indriyani F, Nurhidajah, Agus S. 2013. Karakteristik fisik, kimia dan sifat organoleptik tepung beras merah berdasarkan variasi lama pengeringan. J. pangan dan gizi 4(8): 27-34.

Irmayanti, L.N. 2014. Seleksi tanaman padi generasi $F_{2}$ hasil persilangan IR-64 $x$ Pandanwangi untuk karakter aroma berdasarkan marka molekuler dan pengujian sensori. J. Fakultas Pertanian Vol.1(4)

IRRI. 2009. The Quality Characteristic of Milled Rice are Classified both Physically and Chemically. http://www.knowledgebank. irri.org/rkb/index.php/qualitycharacteristics-of-milled-rice[24/04/2017].

Khan, A.S., M. Imran and M. Ashfaq. 2009. Estimation of genetic variability and correlation for grain yield components in rice (Oryza sativa L.). American-Eurasian J. Agric. Environ. Sci. 6 (5): 585-590.

Kumar, I. and G.S. Khush. 1986. Genetic of amylose content in rice (Oryza sativa L.). J. Genet 65: 1-11.

Ruminta, S. Rosniawaty, A. Wahyudin. 2016. Pengujian sensitivitas kekeringan dan daya adaptasi tujuh varietas padi di wilayah dataran medium Jatinangor. Jurnal Kultivasi Vol. 15(2).

Santoso, S. 2002. Buku Latihan SPSS. Elex Media Komputindo. Jakarta. 342p.

Sekretariat Jenderal Kementrian Pertanian. 2015. Pengujian substantif (Uji Buss). Pvtpp. setjen.pertanian.go.id.

Shannon J.K., D.L. Garwood and C.D. Boyer. 2009. Genetics and Physiology of Starch Development. Starch: Chemistry and Technology, Third Edition. ISBN: 978-012-746275-2.

Tian, Z., Q. Qian, Q. Liu, M. Yan, X. Liu, C. Yan, G. Liu, Z. Gao, S. Tang, D. Zeng, Y. Wan, J. Yu, M. Gu, J. Li. 2009. Allelic diversities in rice starch biosynthesis lead to a diverse array of rice eating and cooking qualities. www.pnas.org

World Health Organization. 2016. Diabetes fakta dan angka. http://www.who.int /factsheets/detail/diabetes 